\title{
Karakteristik Ruang Pembelajaran Menggunakan Kumpulan Karya Simulasi
}

\author{
Octavianus Cahyono Priyanto \\ Program Studi Desain Interior, Fakultas Seni Rupa, Institut Seni Indonesia Yogyakarta \\ Email: o.c.priyanto@gmail.com
}

\begin{abstract}
Abstrak
Mendesain ruang pembelajaran komunal adalah sebuah proses sosial-kreatif yang diyakini dapat menghasilkan desain sesuai harapan jika melibatkan calon penggunanya sebanyak mungkin, namun pada praktiknya hal ini dianggap kurang praktis. Biasanya mereka dilibatkan pada survei preferensi visual secara pasif. Namun kini perkembangan teknologi memungkinkan sejumlah besar partisipan terlibat secara aktif membuat usulan desain melalui platform lingkungan virtual secara daring. Pada penelitian ini 178 usulan ruang pembelajaran melalui platform tersebut dikumpulkan dan dipelajari lebih lanjut dengan melibatkan 5 orang pakar. Pada tahap awal didapatkan 20,79\% mendapat nilai di atas rata-rata. Selanjutnya karakteristik dari masing-masing kelompok tersebut dianalisis dengan melibatkan 53 partisipan. Temuan dari penelitian ini diharapkan dapat memberi gambaran tentang preferensi pengguna mengenai desain ruang pembelajaran komunal yang ideal.
\end{abstract}

Kata kunci: Karakteristik Ruang Pembelajaran, Lingkungan Virtual Daring, Preferensi Pengguna

\begin{abstract}
Designing a communal learning space is a socio-creative process that is believed to be able to produce a design as expected if it involves as many potential users as possible, but in practice this is considered impractical. Usually, they are involved in a visual preference survey passively. But now technological developments allow a large number of participants to be actively involved in making design proposals through online virtual environment platforms. In this study, 178 proposed learning spaces through the platform were collected and studied further by involving 5 experts. In the initial stage, 20.79\% received above average rating. Furthermore, the character of each group was analyzed involving 53 participants. The findings from this study are expected to provide an overview of user expectations regarding the ideal communal learning space design.
\end{abstract}

Keywords: Learning Space Characteristic, Online Virtual Environment, User Preference

\section{Pendahuluan}

Membuat desain ruang pembelajaran yang memberi dampak positif bagi penggunanya membutuhkan banyak pemikiran yang berkaitan dengan berbagai faktor yang saling bersinggungan. Bukan hanya faktor fisik lingkungan, namun juga faktor hubungan sosial yang terjadi di dalam lingkungan belajar seperti hubungan antar teman dan hubungan antara siswa dengan pengajar. Komisi Desain $U K$ menentukan 4 tema utama dalam kompetisi pembelajaran inovatif menentukan 4 tema utama yang perlu mendapat perhatian (Higgins, Hall, Woolner, \& McCaughey, 2005), yaitu (1) Komunikasi, (2) Sistem - Proses, (3) Produk - Layanan, dan (4) Lingkungan. Masing-masing tema ini memiliki kompleksitas masing-masing, namun Higgins et.al saat itu menemukan bahwa kualitas lingkungan fisik paling banyak mendapat perhatian, baik itu kualitas terukur (cahaya, kualitas udara, akustik) maupun tidak terukur (kualitas subyektif). Salah 
satu cara untuk mengukur kualitas lingkungan secara subyektif adalah preferensi pengguna melalui survei pada calon pengguna, contohnya dengan menyebarkan angket sebagai upaya mengumpulkan data preferensi. Contohnya adalah survei preferensi yang dilakukan The University of Sheffield saat pembangunan gedung The Diamond di mana beberapa mahasiswa diundang untuk mencoba dan sejumlah furnitur yang akan digunakan yang dilakukan selama beberapa hari. Namun demikian partisipan tidak terlibat secara aktif mengusulkan kualitas ruang pembelajaran, karena mereka tidak memiliki akses pada alat yang memungkinkan mereka melakukan hal tersebut, ditambah lagi rata-rata calon pengguna bukanlah desainer yang terlatih, sehingga membutuhkan visualisasi untuk mendapat gambaran mengenai kualitas sebuah ruang.

Perkembangan teknologi simulasi komputer telah membuka banyak kemungkinan baru yang belum pernah dilakukan sebelumnya di bidang desain interior, seperti membuat simulasi komputer tiga-dimensi sebagai referensi bagi klien. Secara umum yang dilakukan adalah melibatkan pengguna secara pasif, yaitu dengan memperlihatkan simulasi seperti yang dilakukan Richen dan Trinder (Richens \& Trinder, 1999) kemudian partisipan memberi penilaian melalui email. Cara kedua adalah melibatkan pengguna secara aktif melalui ruang virtual di mana pengguna dapat secara langsung melakukan modifikasi seperti menambah atau mengurangi perkakas, mengganti warna permukaan, ukuran ruang, seperti yang dilakukan Vosinakis (Vosinakis, Azariadis, \& Sapid, 2007). Cara ketiga yang pernah dilakukan adalah dengan melibatkan intelegensi buatan (artificial intelligence) seperti yang diperagakan Nagamachi (Nagamachi \& Lokman, 2010) dengan sistemnya yang disebut HULIS. Namun sangat jarang ditemui penggunaan lingkungan virtual interaktif dikarenakan persiapan yang tidak sedikit.

Pada penelitian sebelumnya, penulis membuat sebuah platform simulasi berbasis lingkungan virtual interaktif yang dinamai $p$-VE (parametric-Virtual Environment). Platform ini dibuat untuk memudahkan pengguna awam memodifikasi ruang virtual untuk dapat menampilkan preferensi visual ruang pembelajaran yang diharapkan. Pengguna dapat mengakses $p$ - $V E$ secara daring tanpa dibatasi ruang ataupun waktu. Melalui antar-muka orang pertama, pengguna dapat mengeksplorasi desain ruang pembelajaran yang sudah disiapkan sebelumnya, kemudian diberi kesempatan untuk melakukan modifikasi sesuai dengan keinginan. Pada versi ini, pengguna dapat mengubah warna permukaan, ukuran ruang, tipe bukaan (jendela) dan langit-langit. Pada eksperimen tersebut, ada 186 partisipan yang terlibat dan masing-masing menghasilkan sebuah artefak berupa 'desain' ruang pembelajaran. Luaran dari penelitian tersebut adalah usulan elemen dan properti visual sebagai referensi bagi desainer untuk digunakan pada desain ruang pembelajaran. Data tersebut dikumpulkan secara otomatis melalui nilai variabel di dalam script tanpa melihat hubungannya dengan elemen lain pada artefak, kemudian dikelompokkan pada masing-masing kategori untuk dapat dilakukan perhitungan statistik deskriptif. Dari masing-masing elemen yang paling banyak terpilih kemudian divisualkan menjadi satu artefak gabungan (Gambar 1). Dikarenakan hasil tersebut didapat dari penggabungan elemen dan properti yang terpilih secara individual, tidak ada jaminan hasil yang didapatkan akan sesuai dengan harapan mayoritas partisipan (Priyanto \& Peng, 2018).

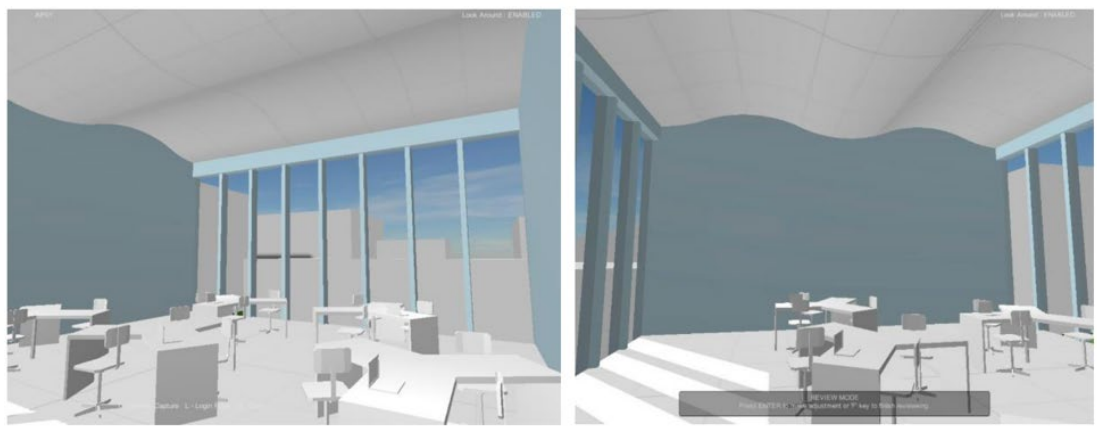

Gambar 1 Artefak gabungan ruang pembelajaran melalui p-VE

(Sumber: Priyanto, 2018) 
Selain itu, penelitian sebelumnya telah menghasilkan artefak individu sebagai karya kreasi dari 186 partisipan yang sebagian besar merupakan mahasiswa perguruan tinggi. Artefak ini merupakan hasil dari partisipan mengekspresikan preferensi mereka menggunakan $p-V E$ setelah mendapat instruksi pada pengantar, yaitu:

"Express your preferences of these following properties: (1) Window and Ceiling Type, (2) Spatial dimensions (3) Ceiling/Wall/Floor color which you think are favorable for learning space."

Walaupun artefak ini dihasilkan hanya dalam waktu relatif singkat dibandingkan proses desain yang sebenarnya, secara sederhana apa yang mereka lakukan juga melalui tahapan-tahapan desain seperti analisa, sintesis, dan evaluasi. Sehingga dapat dikatakan artefak tersebut merupakan sebuah karya desain yang dihasilkan setelah partisipan menganalisis kebutuhan berdasarkan instruksi yang diberikan pada eksperimen terdahulu.

Artefak ini tersimpan dalam bentuk simulasi tiga-dimensi yang bisa dibuka dan dimodifikasi. Namun dikarenakan adanya perubahan media di cloud penyimpanan data p-VE, maka artefakartefak tersebut kemudian disimpan dalam bentuk dua gambar dengan sudut pengambilan gambar berbeda. Namun dari pendataan ulang, hanya ada 178 pasang artefak yang dapat ditemukan.
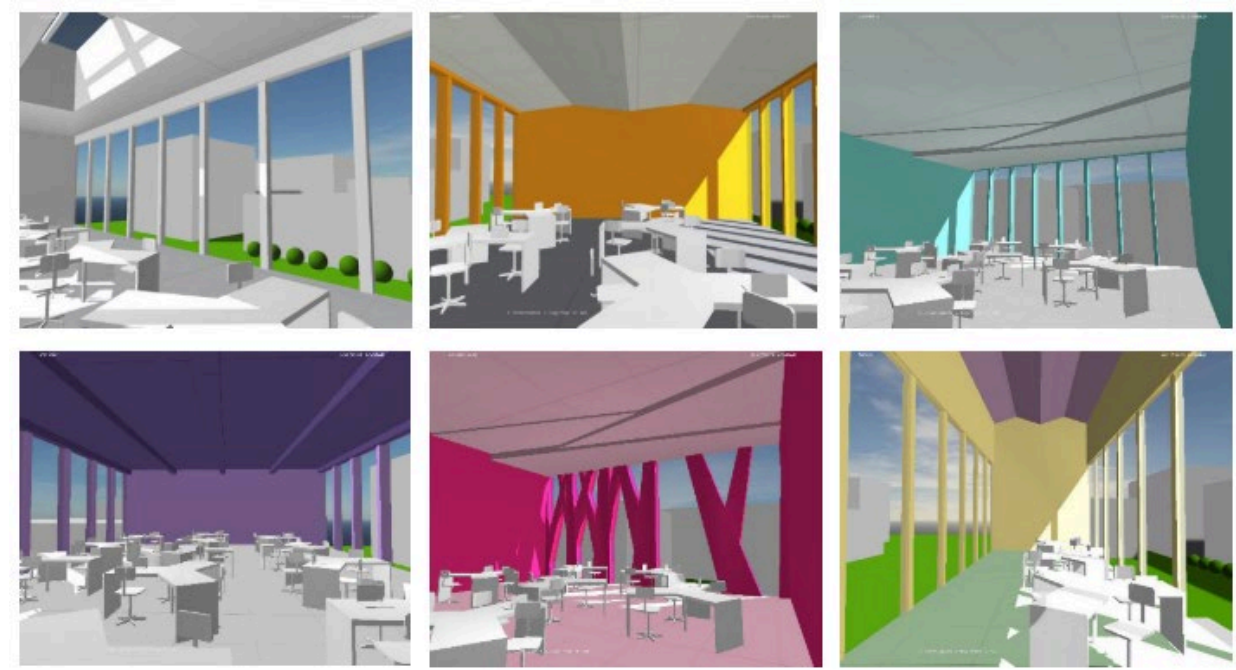

Gambar 2 Contoh 6 dari 178 Artefak individu yang dihasilkan melalui p-VE (sumber: pribadi, 2020)

Kedua kelompok Artefak ini, baik artefak gabungan ataupun artefak individu ini memiliki potensi yang belum tergali. Salah satunya adalah reaksi pengguna terhadap kualitas karya desain tersebut, karena dari reaksi pengguna dapat diperkirakan model desain yang sesuai dengan harapan. Oleh sebab itu pertanyaan dari penelitian ini adalah, karya seperti apakah yang mendapat masuk ke dalam kategori yang dapat diterima oleh pengguna, dan manakah yang sebaiknya dihindari? Jika mengikuti Theodore Sturgeon, seorang pengarang sains-fiksi berkebangsaan Amerika yang menyebut bahwa: "Sembilan puluh persen dari apa pun adalah tidak berguna", apakah benar bahwa nantinya hanya akan ada 10\% dari artefak tersebut yang akan dianggap berguna? Dan yang tidak kalah pentingnya adalah mengenai persepsi subyektif terhadap karakteristik masing-masing kelompok.

\section{Metode}

Untuk menjawab pertanyaan-pertanyaan tersebut, peneliti melibatkan partisipan untuk memberi penilaian pada kumpulan karya tersebut, menentukan kelompok, dan menentukan karakteristik dari masing-masing kelompok tersebut. Metode yang digunakan adalah metode kuantitatif melalui survei preferensi visual. Untuk itu eksperimen dibagi menjadi dua tahap. Eksperimen pertama 
melibatkan partisipan terbatas untuk mengelompokkan keseluruhan artefak berdasarkan 3 kategori, yaitu: (1) Kelompok Netral untuk artefak yang mendapat nilai rata-rata 2; (2) Kelompok A untuk artefak di atas nilai netral; (3) Kelompok B untuk artefak di bawah nilai netral. Eksperimen kedua akan melihat karakteristik dari masing-masing kategori dan dinilai berdasarkan kriteria-kriteria Adjective rating scale seperti yang dipaparkan Sanoff (Sanoff, 1990) pada buku Visual Research Methods in Design. Perangkat ini berisi daftar kata sifat (adjective) yang disusun pada dua sisi kutub ekstrem yang berseberangan. Partisipan yang akan dilibatkan adalah dari mereka yang memiliki latar belakang desain, baik mahasiswa maupun pakar yang sudah memiliki berbagai pengalaman.

Pada tahap pertama tiap peserta memberi penilaian pada artefak. Jika artefak tersebut masuk ke kelompok di atas rata-rata akan mendapat nilai 3, di bawah rata-rata mendapat nilai 1, dan nilai 2 untuk netral. Sanoff berpendapat cukup 5 partisipan yang terlibat untuk memberi penilaian, walaupun secara statistik sampel yang lebih banyak akan memberi hasil yang lebih stabil. Nilai rerata yang diterima masing-masing artefak kemudian digunakan untuk menentukan kategori dari artefak tersebut. Artefak yang berada di atas netral (2) masuk ke kelompok A, sementara di bawah netral masuk ke kelompok B. Untuk kelompok dengan nilai rata-rata tertinggi (3) akan dimasukkan kelompok AA, dan kelompok dengan rata-rata nilai terendah (1) masuk ke kelompok BB. Kedua kategori ini kemudian disertakan pada tahap kedua untuk menentukan karakteristik dari masing-masing kelompok tersebut.

Eksperimen ini dilakukan terhadap Artefak gabungan (Gambar 1) yang akan diberi label C, kemudian kutub tertinggi (AA) dan terendah (BB). Untuk mendapatkan karakteristik dari masingmasing kategori tersebut digunakan adjective rating scale, di mana partisipan akan menilai kelompok tersebut berdasarkan beberapa label, yaitu: Keindahan (buruk - indah); Keceriaan (murung - ceria); Kompleksitas (sederhana - rumit); Kegembiraan (sedih - gembira); Berkesan (tidak berkesan - berkesan); Mengundang (menolak - mengundang); Luas (sempit - luas); Menyenangkan (tidak menyenangkan - menyenangkan); Menarik (tidak menarik - menarik); Disukai (tidak disukai - disukai). Skala yang digunakan adalah 5 titik skala. Survei dilakukan menggunakan google form, undangan disebar melalui media sosial dengan membagikan tautan yang dapat diakses. Konten dapat diakses secara daring melalui perangkat komputer. Namun sebelumnya, peserta diberi penjelasan tentang maksud dan tujuan penelitian, lama penelitian, serta hak-hak mereka selama mengikuti survei.

Tes reliabilitas Cronbach's Alpha (Alfa) digunakan untuk melihat konsistensi dari respon partisipan, dan juga melihat hubungan antar kelompok artefak. Batas (threshold) yang digunakan adalah 0,60 di mana nilai alfa yang lebih tinggi dapat diartikan sebagai adanya konsistensi. Tes konsistensi pada reaksi dari masing-masing partisipan dibutuhkan untuk melihat apakah instrumen penelitian dapat diandalkan. Sementara itu, tes alfa antar kelompok dibutuhkan untuk melihat ada atau tidaknya hubungan.

\section{Eksperimen dan Pembahasan}

Eksperimen pertama melibatkan 5 orang yang berlatar belakang desain dengan lama pengalaman yang berbeda. Dua di antaranya berpengalaman lebih dari 10 tahun sebagai desainer dan pengajar bidang desain interior, dua partisipan adalah lulusan baru, dan seorang masih berstatus mahasiswa. Ke-5 penilai tersebut menilai secara subyektif berdasarkan kualitas visual yang ditampilkan oleh masing-masing artefak. Melalui hasil perhitungan di SPSS, tes alfa dari penilaian oleh juri menunjukkan bahwa nilai alfa yang didapat adalah 0,67 . Nilai ini lebih tinggi dari batas 0,60 yang menunjukkan adanya konsistensi di antara penilai sehingga instrumen penelitian dapat diandalkan. 
Tabel 1 Proporsi Artefak berdasarkan penilaian pakar (Sumber: Pribadi, 2020)

$\begin{array}{cccc}\text { Kelompok } & \text { Kriteria Nilai } & \text { Jumlah } & \% \\ \text { AA } & 3 & 6 & 3.37 \\ \text { A } & \text { Antara } 2 \mathrm{~s} / \mathrm{d} 3 & 37 & 20.79 \\ \text { Netral } & 2 & 17 & 9.55 \\ \text { B } & \text { Antara } 1 \mathrm{~s} / \mathrm{d} 2 & 124 & 69.66 \\ \text { BB } & 1 & 18 & 10.11\end{array}$

Hasil eksperimen pertama menunjukkan bahwa dari 178 artefak, 37 (20,79\%) mendapat nilai di atas netral (2) sehingga masuk kategori A, sedangkan $124(69,66 \%)$ berada di bawah netral sehingga masuk kategori B. Sementara itu ada 17 artefak yang masuk dalam kelompok netral atau mendapat nilai rata-rata 2. Di antara 37 artefak kategori A terdapat 6 yang memperoleh nilai tertinggi (AA) dengan rata-rata 3. Sementara itu di antara 124 artefak kategori B terdapat 18 artefak yang mendapat nilai terendah (BB) dengan rata-rata 1. Dari hasil eksperimen pertama kemudian disusun instrumen pengumpulan data untuk mencari karakteristik dari masing-masing kelompok (Gambar 3).
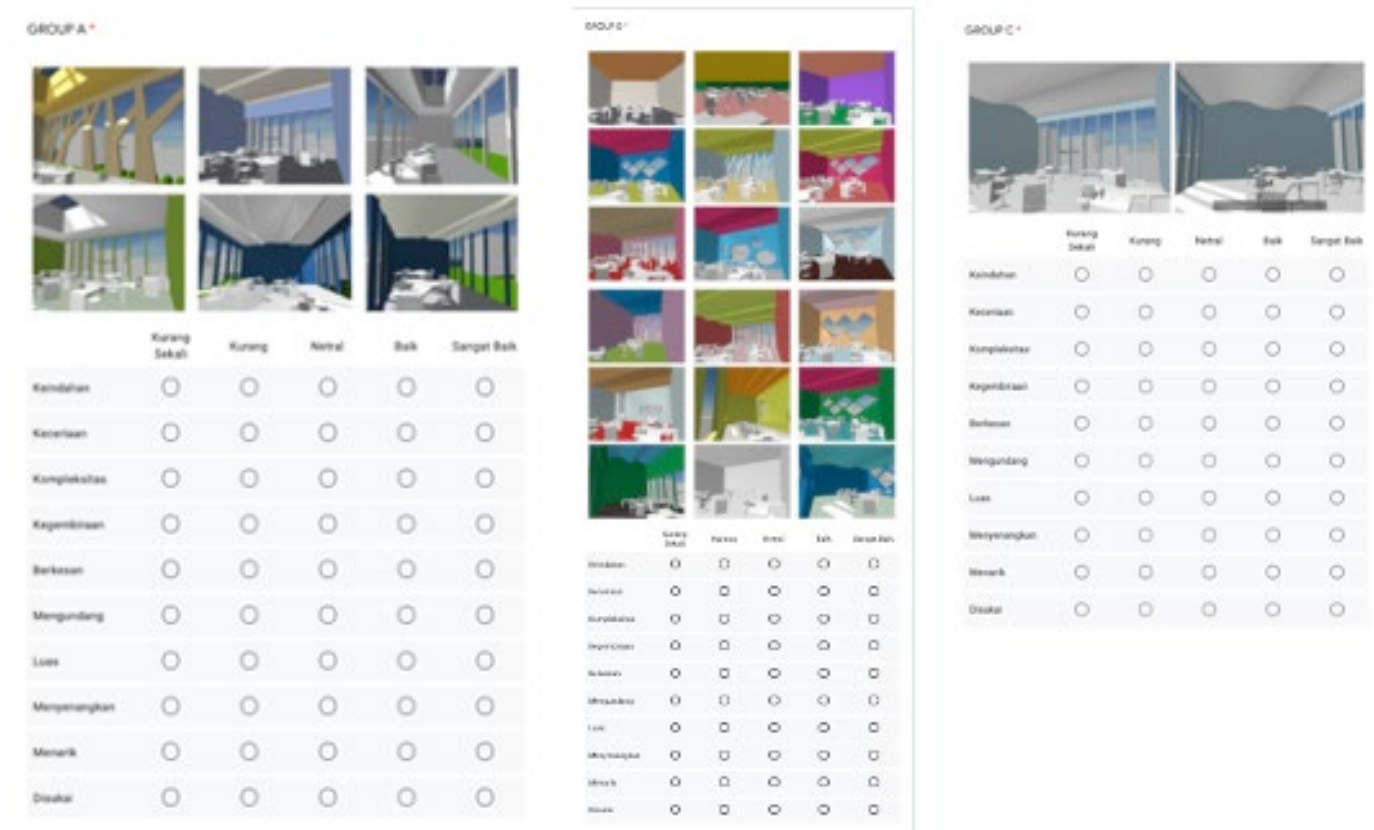

Gambar 3 Instrumen Eksperimen Karakteristik kelompok AA (kiri), BB (tengah), dan C (kanan) (Sumber: Pribadi, 2020)

Eksperimen kedua mendapatkan reaksi dari 53 partisipan dengan proporsi 34 orang berlatar belakang desain, dan 20 orang tanpa latar belakang desain. Hasil yang didapat dari survei karakteristik menggunakan adjective rating scale (Gambar 3), sebagai ruang pembelajaran kelompok AA dan C sama-sama lebih disukai oleh partisipan dibanding kelompok BB. Selain itu keduanya juga dinilai memiliki nilai dari sisi keindahan, lebih mengundang, berkesan luas, serta dianggap lebih menarik. Sementara itu kelompok BB dinilai lebih ceria, kompleks, memberi kegembiraan, serta lebih menyenangkan dibanding kelompok lain. Secara visual, kelompok tersebut memang banyak menggunakan warna-warna yang memiliki saturasi tinggi. Hal yang menarik untuk diperhatikan adalah, walaupun dianggap lebih ceria, gembira dan menyenangkan, 
hal ini tidak membuat artefak di kelompok ini lebih disukai dibanding kelompok AA dan C sebagai ruang pembelajaran.

Tabel 2 Perolehan rata-rata tiap kelompok (sumber: Pribadi, 2020)

\begin{tabular}{|c|c|c|c|c|c|c|c|c|c|c|}
\hline Kelompok & Indah & Ceria & Kompleks & Gembira & Berkesan & Mengundang & Luas & Menyenangkan & Menarik & Disukai \\
\hline $\mathrm{AA}$ & 0.85 & 0.22 & 0.43 & 0.28 & 0.67 & 0.69 & 1.02 & 0.54 & 0.76 & 0.74 \\
\hline $\mathrm{BB}$ & 0.17 & 0.93 & 0.63 & 0.83 & 0.59 & 0.46 & 0.31 & 0.61 & 0.48 & 0.31 \\
\hline $\mathrm{C}$ & 0.69 & -0.04 & 0.35 & -0.04 & 0.48 & 0.52 & 1.17 & 0.31 & 0.63 & 0.72 \\
\hline
\end{tabular}

Dari Tabel 2 terlihat karakteristik dari masing-masing kelompok yang merupakan nilai rata-rata dari 53 partisipan tidak terlihat nilai yang terlalu menonjol dengan rentang berada di antara $-0,04$ s/d 1,17. Di antara 10 label terlihat sifat paling dominan di kelompok AA adalah kesan luas $(1,02)$, sementara yang paling rendah adalah keceriaan $(0,22)$ namun demikian nilainya masih di atas netral. Sementara itu sifat kelompok BB yang paling menonjol adalah keceriaan $(0,93)$ dan terendah adalah keindahan $(0,17)$. Kelompok $\mathrm{C}$ adalah artefak gabungan yang didapat dari penelitian terdahulu, di mana pada tahap ini mendapat nilai tertinggi pada sifat luas $(1,71)$ dan nilai terendah ada pada sifat Ceria $(-0,04)$ dan Gembira $(-0,04)$. Gambar 4 memperlihatkan secara visual pola hubungan ketiga kelompok tersebut, di mana kelompok AA dan C memiliki pola yang serupa.

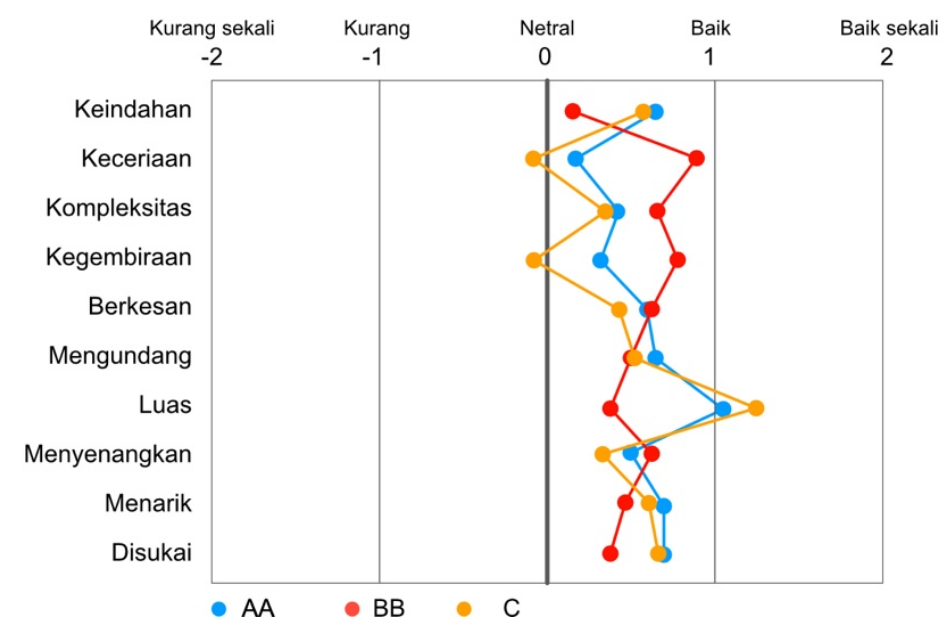

Gambar 4 Perbandingan karakteristik kelompok AA, BB, dan C (Sumber: Pribadi, 2020)

Tes alfa juga mengkonfirmasi kedua kelompok ini memiliki kedekatan hubungan nilai 0,91 . Sebaliknya perbandingan kelompok AA dan BB mendapat nilai alfa negatif atau berlawanan.

\section{Simpulan}

Dari hasil penelitian, telah dikelompokkan artefak dengan berbagai tingkatan ditinjau dari sisi manfaat untuk pengembangan desain. Dalam kasus ini didapat 20,79\% yang dianggap memiliki nilai di atas rata-rata sehingga melebihi ekspektasi hukum Sturgeon. Sementara itu 9,55\% masuk dalam kategori netral, dan $69,66 \%$ di bawah rata-rata. Penelitian ini menunjukkan bahwa kelompok $\mathrm{C}$ yang merupakan hasil dari penelitian terdahulu memiliki kesamaan karakteristik 
dengan artefak kelompok AA yang mendapat nilai di atas rata-rata, dan memiliki karakteristik yang berlawanan kelompok BB.

Faktor keluasan ruang adalah karakteristik yang paling dominan dalam menentukan kualitas visual ruang pembelajaran yang diharapkan, diikuti oleh keindahan. Sementara itu, karakteristik Ceria dan Gembira yang sering kali dianggap penting justru menjadi dua karakteristik terendah yang diharapkan hadir di ruang pembelajaran komunal ini. Bisa jadi keberadaan stimulasi tersebut dianggap tidak relevan pada kegiatan pembelajaran, dan ini didukung dari hasil pengelompokan bahwa desain dengan warna-warna dengan saturasi tinggi tidak menjadi pilihan terbaik dari para pakar.

Koleksi karya dari para partisipan tersebut diharapkan telah mengakomodasi pengguna dengan berbagai macam latar belakang. Namun demikian, jika proses demokrasi dalam desain benar-benar diterapkan, permasalahan berikutnya adalah saat menentukan arah desain, karena kelompok dengan nilai di atas rata-rata adalah minoritas.

\section{Daftar Pustaka}

Higgins, S., Hall, E., Woolner, P., \& McCaughey, C. (2005). The impact of school environments: A literature review. London: Design Council.

Nagamachi, M., \& Lokman, A. M. (2010). Innovations of Kansei Engineering (1st ed.). Florida: CRC Press.

Priyanto, O. C., \& Peng, C. (2018). Influences of visual preferences expressed by participants on early stage of learning space design: an interactive parametric modelling study. Architectural Science Review, 454-466. https://doi.org/10.1080/00038628.2018.1483887

Richens, P., \& Trinder, M. (1999). Design participation through the Internet: A case study. Architectural Research Quarterly, 361-374. https://doi.org/10.1017/S1359135500002256

Sanoff, H. (1990). Visual Research Methods in Design. New Jersey: John Wiley \& Sons Inc.

Vosinakis, S., Azariadis, P., \& Sapid, N. (2007). A Virtual Reality Environment Supporting the Design and Evaluation of Interior Spaces. 4th International INTUITION Conference (hal. 43-51). Athens, Greece: Interaction Design Foundation. 
Lintas Ruang: Jurnal Pengetahuan \& Perancangan Desain Interior | Vol 8 No 2 Th. 2020 | Hal 19-25 